\title{
S KNJIŽNICOM \\ DO POSLOVNOG USPJEHA
}

\author{
WITH THE LIBRARY \\ TO SUCCESS IN BUSINESS
}

Milka Šupraha-Perišić
Gradska knjižnica Rijeka
milka.supraha-perisic@gkri.hr

Ana Ribarić

Gradska knjižnica Rijeka

ana.ribaric@gkri.hr

UDK / UDC 027(497.5 Rijeka):658

Stručni rad / Professional paper

Primljeno / Received: 5. 11. 2018.

Prihvaćeno / Accepted: 27. 1. 2019.

\section{Sažetak}

Cilj. Ovim radom željelo se pokazati iskustva Gradske knjižnice Rijeka pri pokretanju i realizaciji usluge Poslovni kutak, usluge usmjerene na poslovne informacije i e-usluge kao potporu građanima za bolje snalaženje u svijetu rada i poduzetništva. Također se željela saznati struktura korisnika Poslovnog kutka te razina zadovoljstva navedenom uslugom.

Metodologija. U uvodnom dijelu rada opisana je motivacija za pokretanje usluge s naglaskom na međunarodne dokumente na koje se oslanja. Slijede primjeri dobre prakse u svijetu i Hrvatskoj. Usluga Poslovni kutak opisana je kroz ciljeve, ljudske, tehnološke i druge resurse, sadržaj rada i promotivne aktivnosti. Na temelju evaluacijskih listića koje ispunjavaju svi sudionici i posjetitelji događanja u Poslovnom kutku napravljena je analiza strukture korisnika, kao i procjena razine zadovoljstva uslugom.

Vjesnik bibliotekara Hrvatske 61, 2(2018), 437-452

ISSN 0507-1925

(C) VBH 2018. 
Rezultati. Rezultati su pokazali veliku zainteresiranost građana za sadržaje koje pruža usluga Poslovni kutak u lokalnoj zajednici, a trend pokazuje da zainteresiranost stalno raste. Žene su proaktivnije od muškaraca (63 \%). Nečlanovi Knjižnice čine čak $35 \%$ korisnika. Sukladno očekivanjima, $60 \%$ korisnika usluge u dobi je od 26 do 45 godina. Zaposlene osobe čine $55 \%$ korisnika, a nezaposlene $17 \%$. Iskazano je veliko zadovoljstvo izborom tema i korisnošću informacija. Facebook je najznačajniji komunikacijski kanal za promociju usluge.

Originalnost/vrijednost. Uključujući se u procese snaženja poduzetničkog duha, Knjižnica čini iskorak iz dosadašnjih praksi, a pozitivna evaluacija usluge temeljena na ocjenama korisnika i brojnosti onih koji sudjeluju u projektu (suradnika i sudionika) to i potvrđuje. Programi narodnih knjižnica za korisnike tradicionalno se kreću unutar područja obrazovanja i kulture. Širenjem usluga na poslovni i radni aspekt života, narodna knjižnica na nov način privlači pozornost i vrednovanje od strane građana.

Ključne riječi: knjižnične usluge, narodne knjižnice, poslovna knjižnica, poslovni kutak

\begin{abstract}
Aim. This paper presents the experiences of the Rijeka City Library in starting and realizing the Business Corner service - a service aimed at providing business information and e-services, as a support to citizens in coping with the world of business and entrepreneurship. It also analyzes the structure of the Business Corner users and their level of satisfaction with this service.
\end{abstract}

Methodology. In the introductory part, the motivation for starting the service is described, with specific reference to the relevant international documents on which it is based. This is followed by good practice examples, both in Croatia and around the world. The Business Corner service is described through its aims, human, technological and other resources, contents of the service, and promotional activities. Through the analysis of the evaluation forms given to all participants and visitors of Business Corner events, the users structure has been outlined and their satisfaction with the service assessed.

Results. The results have shown a great interest of the citizens for the contents that the Business Corner service offers to the local community. The trend shows a constant growth of interest. Women are more proactive in comparison to men (63\%). $35 \%$ of the users are not Library members. As expected, $60 \%$ of the users are aged between 26 and 45 years. $55 \%$ of the users are employed, while $17 \%$ are unemployed. The users have shown great satisfaction with the choice of topics and the usefulness of information. Facebook is the most important communication channel, as far as the promotion of the service is concerned.

Originality/value. By participating in the process of strengthening the spirit of entrepreneurship, the library is moving away from the usual practice, which is confirmed 
by the positive evaluation of the service by its users and the number of those participating in the project (associates and participants). Traditionally, public library programmes aimed at library users are focused mainly on education and culture. By expanding the service to include business and working aspects of life, the public library attracts the attention and evaluation of the public in the new way.

Keywords: business corner, business libraries, library services, public libraries

\section{Uvod}

Narodne knjižnice odavno su prestale biti isključivo baštinske ustanove. One u svoje tradicionalne usluge integriraju čitav niz novih usluga koristeći informacijske tehnologije, ne zbog tehnologija samih već zbog usluga koje kroz njih provode i promiču. Tradicionalna knjižnica uglavnom je brinula o svojim korisnicima, manje o povremenim korisnicima, a nikako o nekorisnicima. Mnogi podaci govore da se broj korisnika tradicionalnih knjižničnih usluga u Europi smanjuje te su knjižnice primorane stvarati novu publiku. ${ }^{1}$ Globalizacijski procesi s jedne, a razvoj tehnologije s druge strane, stavili su pred prosječnog građanina imperativ digitalne pismenosti kao preduvjet za snalaženje u svijetu rada i poduzetništva. U tom su se smislu narodne knjižnice, kao mjesta velikog povjerenja građana, nametnule kao idealan komunikacijski kanal između javnih servisa središnje i lokalne države i građana.

Ideja poslovne knjižnice ${ }^{2}$ javlja se u sinergiji s općim naporima društva za jačanje poduzetničke klime u zajednici, a može se ostvarivati u okviru informacijske uloge kako narodnih knjižnica tako i drugih tipova knjižnica.

Potpora za razvoj navedene usluge u knjižnicama nalazi se u gotovo svim domaćim i međunarodnim dokumentima. U Pulmanovim smjernicama ${ }^{3}$ navodi se da narodne knjižnice pružaju svojim korisnicima usluge i iz sljedećih područja društvenog života:

- Društvena inkluzija

- E-vlada i građansko pravo

- Informacijske usluge za društveni i gospodarski razvitak - potpora poduzetništvu i gospodarstvu.

\footnotetext{
1 Horvat, A. Knjižnice u službi svoje zajednice. // Knjižnica kao komunikacijsko i multikulturalno središte lokalne zajednice / 8. Savjetovanje za narodne knjižnice u Republici Hrvatskoj; priredila za tisak Jelica Leščić. Zagreb: Nacionalna i sveučilišna knjižnica, 2012. Str. 26-27.

2 Poslovna knjižnica, poslovni knjižničar i poslovni kutak nazivi su za knjižničnu uslugu posredovanja poslovnih informacija, poslovnog savjetovanja i poslovne edukacije.

3 Pulman-smjernice. [citirano: 2018-09-20]. Dostupno na: https://gkr.hr/content/ download/1799/20700/.../2/.../Pulman\%20smjernice\%20(1).doc.
} 
IFLA-in program IAP ${ }^{4}$ osmišljen je s ciljem da bude potpora knjižnicama i knjižničarima u provedbi UN-ove Agende $2030^{5}$, gdje je područje rada, poduzetništva, ekonomije i održivosti naglašeno kroz više ciljeva Agende:

- Cilj 4: Kvalitetno obrazovanje (naglasak na cjeloživotnom učenju)

- Cilj 5: Rodna ravnopravnost (doprinos uključivanju većeg broja žena u poduzetničke aktivnosti)

- Cilj 9: Industrija, inovacije i infrastruktura

- Cilj 10: Smanjenje nejednakosti

- Cilj 11: Održivi gradovi i zajednice (podizati svijest o poboljšanju urbanog života).

\section{Primjeri poslovnih knjižnica u svijetu i Hrvatskoj}

Trend u kojem narodne knjižnice predstavljaju važne institucije za potporu lokalnoj ekonomiji proširio se iz Sjedinjenih Američkih Država. Tijekom 2015. Veleposlanstvo SAD-a u suradnji s knjižnicom Ekonomskog fakulteta u Zagrebu i Hrvatskim knjižničarskim društvom provodi zajednički projekt Work With Us tijekom kojega je održan niz predavanja na temu uloge poslovnih knjižnica unutar narodnih knjižnica s ciljem stvaranja informacijskih središta za potporu malom i srednjem poduzetništvu u lokalnim zajednicama. ${ }^{6}$ Usluga poslovne knjižnice zaživjela je u Gradskoj knjižnici „Ivan Goran Kovačić“" Karlovac ${ }^{7}$, a usmjerena je uglavnom na poticanje poduzetničkih kompetencija mladih. U europskom prostoru ulogu poslovne knjižnice najcjelovitije obavlja jedna nacionalna knjižnica, The British Library, čiji poslovni centar The British Library's Business \& IP Centre ${ }^{8}$ prednjači svojom kadrovskom, infrastrukturnom i financijskom opremljenošću.

\footnotetext{
4 IFLA. International Advocacy Programme (IAP). [citirano: 2019-1-3]. Dostupno na: https:// www.ifla.org/ldp/iap.

5 Novi izazov: globalni ciljevi održivog razvoja do 2030. Zagreb: Odraz, 2015. [citirano: 2019-10-1]. Dostupno na: http://odraz.hr/media/291518/globalni\%20ciljevi\%20odrzivog\%20 razvoja\%20do\%202030_web.pdf.

6 Udiljak Bugarinovski, Z.; D. Pšenica. Poslovna knjižnica. // Knjižnice: kamo i kako dalje?: zbornik radova / 14. dani specijalnih i visokoškolskih knjižnica; uredile Dina Mašina i Kristina Kalanj. Zagreb: Hrvatsko knjižničarsko društvo, 2017. Str. 217-225.

7 Poslovna knjižnica. // Gradska knjižnica „Ivan Goran Kovačić“ Karlovac [citirano: 2018-101]. Dostupno na: http://www.gkka.hr/poslovna-knjiznica/.

8 The British Library's Business \& IP Centre. [citirano: 2018-10-1]. Dostupno na: https://www. bl.uk/business-and-ip-centre.
} 


\section{Poslovni kutak GKR}

Planiranju usluge Poslovnog kutka pristupilo se projektno, tj. definirani se ciljevi, rokovi i raspoloživi resursi (tehnološki, ljudski i ostali). Inicijalno je formiran tim od devet zaposlenika (uključujući koordinatora, predlagatelja usluge) različite dobi, iskustava i interesa, koji su kroz šest mjeseci nizom radnih dogovora i konzultacija definirali uslugu.

\subsection{Ciljevi:}

1. Usluga poslovne knjižnice specifično je usmjerena prema poslovnim informacijama i izvorima s ciljem podizanja lokalne ekonomije, a na način da građani poslovne informacije mogu naći na jednome mjestu, tj. da knjižnica bude središnje mjesto lokalne zajednice za teme poduzetništva, zapošljavanja, poslovne motivacije, javne potpore gospodarskim aktivnostima i sl. Time Gradska knjižnica Rijeka kroz svoju informacijsku ulogu ostvaruje i ulogu sprečavanja društvene isključenosti i siromaštva.

2. Gradska knjižnica Rijeka povezuje se kroz Poslovni kutak sa svim lokalnim dionicima s područja poduzetništva i zapošljavanja koji su otvoreni za suradnju.

3. Pokretanjem Poslovnog kutka Gradska knjižnica Rijeka kao narodna knjižnica čini iskorak iz dosadašnjih praksi te svoje usluge s područja kulture i obrazovanja proširuje i na ostala područja života, u konkretnom slučaju na područje rada, zapošljavanja, ekonomije i financija.

4. Pokretanjem usluge Poslovnog kutka Knjižnica se približava ideji knjižnice kao „trećeg prostora“9 i poboljšava vlastiti imidž u zajednici.

\subsection{Resursi (prostorni, tehnološki, ljudski, ostali)}

Prostorni uvjeti i građa. U nedostatku fizičkoga prostora rukovodilo se idejom da je knjižnica dinamičan i promjenjiv sustav te se dio prostora Referentne zbirke koja se sve manje koristi prenamijenio u Poslovni kutak. Iz Referentne zbirke izlučilo se nefunkcionalnu građu i u dobiveni prostor smjestilo građu Poslovnog kutka kojoj se prethodno u računalnoj bazi promijenilo lokaciju te iz korpusa poslovne literature općeg fonda dobilo zbirku Poslovnog kutka čija su osnovna obilježja aktualnost, recentnost i poticajnost. Zbirku se obnovilo inozemnom literaturom. Izradilo se bilten poslovne literature koji je svima dostupan u tiskanom

9 Velagić, Z. Povijesnost koncepcije knjižničnoga trećeg prostora. // Narodne knjižnice kao treći prostor: zbornik radova / 9. savjetovanje za narodne knjižnice u Republici Hrvatskoj. Zagreb: Nacionalna i sveučilišna knjižnica, 2015. Str. 29-42. 
obliku. Iz čitaonice časopisa prenijelo se određeni broj naslova periodike koji kontinuirano pristižu i upotpunjuju zbirku.

Ljudski resursi. $U$ fazi pripreme usluge svatko od članova tima na neki je način pridonio definiranju usluge. Međutim uslugom će se trajno baviti dvoje stručnih ljudi (od kojih je jedan koordinator usluge), kojima će bavljenje tom uslugom biti dodatni posao uz redovne zadaće. Odmah se prionulo pozivu na suradnju ustanovama i pojedincima, među kojima se ističu: Zavod za zapošljavanje Rijeka, start up-inkubatori (StepRi, Start up, Porin, Silos, Pins), lokalne razvojne agencije u skupini Terraliburna, Visoka poslovna škola PAR, HGK Rijeka, HOK PGŽ-a, TZ Kvarnera te niz kreativnih pojedinaca specijaliziranih za pojedine aspekte poduzetništva.

Ostali resursi. Prikupila su se iskustva dobre prakse koja su bila dostupna (domaća i strana). Računalna oprema osigurana je sponzorstvom. Iskoristile su se vještine dizajniranja novozaposlene kolegice, napravljen je logo Poslovnog kutka i dizajniran prostor. Prionulo se izradi promidžbenih materijala. Promidžbene materijale svih suradničkih ustanova smjestilo se u prostor Poslovnog kutka, na korisnicima dostupno mjesto. Na mrežnim stranicama Knjižnice otvorena je stranica Poslovni kutak koja je potom opremljena informacijama.

\subsection{Realizacija}

Poslovni kutak pokrenut je 9. svibnja 2017. godine kao mjesto razumijevanja i približavanja poslovne problematike svim zainteresiranim građanima, suradnje svih dionika koji građanima nude različite oblike savjetodavne, mentorske, infrastrukturne, financijske i druge podrške te kao mjesto zajedničke sinergije za jačanje poduzetničke kulture i podizanje cjelokupne ekonomske aktivnosti u lokalnoj zajednici.

Gradska knjižnica Rijeka time postaje mjesto:

- potpore građanima za snalaženje na tržištu rada

- pružanja informacijskih usluga s ciljem podizanja lokalne ekonomije

- objedinjenosti poslovnih informacija (poduzetništvo, zapošljavanje, poslovna motivacija, poduzetnički inkubatori, EU fondovi itd.)

- informiranja o lokalnim potpornim institucijama za provedbu temeljnih strateških i programskih ciljeva ekonomskog razvoja te drugih subjekata koji se bave poduzetništvom

- potpore stvarnim i potencijalnim korisnicima za korištenje državnog portala e-Građani te e-Usluga Grada Rijeke

- savjetovanja i edukativnih predavanja

- stvaranja poduzetničke klime među mladima

- socijalne inkluzije. 


\section{Sadržaj rada Poslovnog kutka - jednogodišnji pregled (tematski i kvantitativno)}

\subsection{Teme u Poslovnom kutku}

U planiranju aktivnosti Poslovnog kutka usredotočilo se na teme za koje se tada procijenilo da su u središtu interesa građana i poslovne javnosti:

\section{- Edukacija građana za korištenje središnjeg državnog portala e-Građani i e-Usluge grada Rijeke}

Smatrajući da je digitalna pismenost polazna točka poslovne kulture, krenulo se od edukacije za korištenje državnog portala e-Građani. Pripremajući se za tu uslugu, najprije se educiralo same zaposlenike. Informiralo se o iskustvima Knjižnica grada Zagreba koji su tu uslugu već imali u svojoj praksi. Obavijestilo se o namjerama Ministarstvo uprave i MUP-a te dobilo njihovu suglasnost. Potom je izrađen letak u kojemu se poziva građane da koriste Poslovni kutak GKR kako bi besplatno u prijateljskom okruženju stekli vještine za korištenje te usluge s različitim vjerodajnicama i razinama uvida u vlastite podatke. Letak je distribuiran na frekventna mjesta (banke, Infocentar Grada...). Prema Portalu otvorenih ${ }^{10}$ podataka Republike Hrvatske sustav e-Građani koristilo je otprilike $10 \%$ ukupnog stanovništva Republike Hrvatske. Usprkos tomu što je korištenje sustava besplatno, brzo i jednostavno, problem predstavlja nedovoljan interes za njegovo korištenje. S obzirom na činjenicu da je u sklopu Poslovnog kutka Gradske knjižnice Rijeka uslugu koristilo tek desetak korisnika, Knjižnici predstoji zadaća boljeg promoviranja usluge.

\section{- Kako do sredstava EU-fondova?}

Izradilo se informativni letak koji sadrži osnovne proceduralne upute o uvjetima natječaja za sredstva EU-fondova, najpreglednije mrežne adrese s korisnim informacijama te popis najnovije literature o EU-fondovima. Pozvalo se na suradnju istaknute sugrađane, stručnjake koji rade na pripremi natječaja za EU-fondove, $u$ pravilu mlade ljude, entuzijastične i spremne na suradnju, koji će u probnom razdoblju biti voditelji radionica za građane.

\section{- Što se sve može kroz poduzetničke inkubatore?}

Na suradnju se pozvalo i najvažnije poduzetničke inkubatore grada Rijeke i Županije primorsko-goranske koji su se redom odazvali. Iz redova njihovih vanjskih suradnika dobiveni su predavači/voditelji radionica za različite poslovne teme. Interes za suradnju bio je obostran: poduzetnički inkubatori promoviraju svoje

10 E-Građani - statistika. [citirano: 2018-12-27]. Dostupno na: https://data.gov.hr/dataset/egradjani-statistika. 
aktivnosti kroz Knjižnicu kao najfrekventniji gradski prostor velikog povjerenja građana, dok Knjižnica postaje informacijska točka za poslovne teme.

\section{- Mjere aktivne politike zapošljavanja (HZZ) i druge agencije za zapošlja- vanje}

Tema rada i zapošljavanja otvorena je predavanjem Radna mjesta budućnosti kroz koje smo osvijetlili sve aspekte rada društva budućnosti, a nastavljena predavanjem Roboti dolaze - što ćeš ti raditi kad odrastešs?

Na suradnju se odmah bezrezervno odazvao i Zavod za zapošljavanje Rijeka i ponudio svoje stručne suradnike za predavače u Poslovnom kutku s aktualnostima i pogodnostima koje Republika Hrvatska osigurava za različite skupine građana (nezaposlene, žene, mlade...).

\section{- Razno}

Na suradnju se također odazvala Poslovna akademija Rijeka (PAR) i ponudila svoje nastavno osoblje za predavače, ali i za druge vidove suradnje, između ostaloga i kao partner u projektu. Turistička zajednica Kvarnera prepoznala je Gradsku knjižnicu kao partnera u distribuciji korisnih obavijesti za sve koji se bave bilo kojom vrstom turističke aktivnosti te prihvatila suradnju koja se kvalitetno nastavlja. Uspostavilo se partnerstvo s većim brojem stručnjaka u pojedinim aspektima poslovnog i poduzetničkog života (racionalno upravljanje vremenom, komunikacijske vještine, profesionalni portfolio, brendiranje proizvoda, oglašavanje...) koji su kao izuzetni pojedinci prepoznali u Poslovnom kutku novu vrijednu uslugu Knjižnice i podržavaju je dijeleći znanje i vještine građanima.

\subsection{Građa i informativni materijali}

Poslovna literatura vezana uz poduzetničke mogućnosti, pokretanje vlastitog posla, najbolje načine realizacije i prezentacije ideja, pisanje poslovnih planova, poduzetničke inkubatore i tajne uspješnog poslovanja, motivaciju i jačanje samopouzdanja, biografije uspješnih ljudi i tvrtki, napredovanje i razvoj karijere, marketing, poslovni bonton, EU-fondove i ostale teme koje se bave poslovnom problematikom, nadograđuje se i dopunjuje aktualnim naslovima na hrvatskom i engleskom jeziku. Bilten poslovne literature redovito se ažurira pristiglim novitetima i na raspolaganju je u tiskanom obliku svim zainteresiranim korisnicima.

Zbirka sadrži 205 jedinica recentne i aktualne poslovne literature. U 2017. 168 korisnika posudilo je 277 sv. građe; u 2018. (1.-8. mj.) 219 korisnika posudilo je 404 sv. građe, čime je posudba građe Poslovnog kutka u 2018. porasla za $40 \%$.

Izrađeni su informativni letci o EU-fondovima, poduzetničkim inkubatorima Primorsko-goranske županije, agencijama za zapošljavanje, e-uslugama, kao i 
opći letak svih usluga koje pruža Poslovni kutak, te su smješteni u funkcionalno i vizualno opremljen prostor.

Facebook-stranica Poslovnog kutka kreirana je u rujnu 2017. godine. Iz ukupno 166 oznaka „sviđa mi se“, dvanaest kreiranih događaja za najavu predavanja i 448 korisnika zainteresiranih za njih vidljivo je da se profilirala manja, ali iznimno zainteresirana skupina redovitih pratitelja aktivnosti Poslovnog kutka putem te društvene mreže. Putem Facebook-stranice najavljuju se edukativna predavanja i radionice koje se održavaju u prostoru Poslovnog kutka, promoviraju noviteti poslovne literature, kao i zanimljive i korisne Facebook-stranice, blogovi te online magazini koji uče i inspiriraju. Redovito se na stranici objavljuju i fotografije koje dokumentiraju održane događaje.

\subsection{Kako se usluge Poslovnog kutka promoviraju u lokalnoj zajednici $i$ šire}

Uz redovne promotivne aktivnosti putem mrežne stranice Gradske knjižnice Rijeka, Facebook-stranice Poslovnog kutka i Gradske knjižnice Rijeka te promidžbenih materijala u svim odjelima i ograncima GKR-a, aktivno se uključilo u brojne aktivnosti za povećanje vidljivosti Poslovnog kutka, a sve s ciljem predstavljanja i približavanja usluge široj javnosti.

- 31. 8. 2017. PAR Poduzetnički kamp 2017. - završna manifestacija na Trsatskoj gradini - štand s materijalima Poslovnog kutka

- 2. 10. 2017. Štand na Korzu - predstavljanje Poslovnog kutka povodom Tjedna cjeloživotnog učenja

- 8. 11. 2017. DaNTe 2017 - Dan novih tehnologija - izlaganje na temu Nepodnošljiva lakoća pristupanja e-Uslugama u GKR

- 17. 11. 2017. 5. forum Mladi u poduzetništvu (Centar tehničke kulture) predstavljanje aktivnosti Poslovnog kutka

- 14. 12. 2017. Intervju s Damirom Medvedom u Novom listu potaknut gostovanjem u Poslovnom kutku

- 2017. Od ideje do realizacije usluge - POSLOVNI KUTAK Gradske knjižnice Rijeka, prilog u časopisu Knjižničar/Knjižničarka Knjižničarskog društva Rijeka

- 2018. Poslovni kutak kao primjer dobre prakse glede ostvarivanja ciljeva UN Agende (uz mapu knjižnica koje su sa svojim primjerima stavljene na IFLA-ine mrežne stranice)

- Najava svakog događanja u Poslovnom pulsu, prilogu Novog lista koji uređuje Hrvatska gospodarska komora (Rijeka) 
- 43. Skupština HKD-a, Opatija, 2018. (S knjižnicom do poslovnog uspjeha)

- Sudjelovanje na Rijeci psihologije 2019.

\subsection{Predavanja/radionice}

U pilot-fazi koja je trajala dva mjeseca od otvorenja Poslovnog kutka održano je šest predavanja/radionica, i to utorkom od $13.30 \mathrm{~h}$, koje su bile tematski vezane uz načine pribavljanja bespovratnih sredstava iz nacionalnih programa i EU-fondova, robotiku kao platformu za učenje i inovacije, mjere aktivne politike zapošljavanja Hrvatskog zavoda za zapošljavanje, različite načine upravljanja osobnim financijama, projekt brendiranja obiteljskog smještaja na Kvarneru te Europsku poduzetničku mrežu. Predavanjima i radionicama ukupno je prisustvovalo 146 polaznika, uz predavače zaposlenike suradničkih institucija Poslovnog kutka Gradske knjižnice Rijeka.

Od rujna 2017. do lipnja 2018. godine predavanja/radionice dobivaju novi termin održavanja, utorkom od $18.30 \mathrm{~h}$, u kojem je realizirano 17 predavanja/radionica. Novi termin u predvečerje pokazao se kao idealan izbor te je u navedenom razdoblju predavanjima/radionicama prisustvovao 561 polaznik.

Za ilustraciju se navode neki od naslova predavanja/radionica održanih u Poslovnom kutku:

- Petra Stanković: „Uvod u Facebook: kako iskoristiti Facebook i povećati prodaju?“

- Jana Blažević Marčelja: „Kako krenuti? Obrt, j.d.o.o., d.o.o... što je bolje?““

- Ani Gerbin: „Priprema i provedba EU-projekata: prilike, izazovi, trikovi i zamke“

- Andrea Oštrić Petropoli: „Izvori financiranja - savjeti za poduzetnike početnike i male tvrtke“"

- Nela Dunato: „Totalno drukčiji od drugih - kako stvoriti prepoznatljiv brend svoje male tvrtke“

- Damir Medved: „Roboti dolaze - što ćeš ti raditi nakon školovanja?“

- Ozren Burić: „Google oglašavanje: kako pokoriti tražilice?“

\subsubsection{Evaluacija predavanja/radionica}

S ciljem praćenja zadovoljstva polaznika predavanja/radionica, izrađeni su evaluacijski listići koje je za potrebe istraživanja ispunilo njih 441 . 
Od 441 polaznika predavanja/radionica, njih 287 ili $65 \%$ članovi su Gradske knjižnice Rijeka, dok 154 (35\%) polaznika nisu učlanjena. Predavanja/radionice Poslovnog kutka Gradske knjižnice Rijeka posjetila su 163 muškarca ili $37 \%$ te 278 (63\%) žena. Najveći dio, njih 421 (95\%), zainteresiran je za buduća predavanja/radionice.

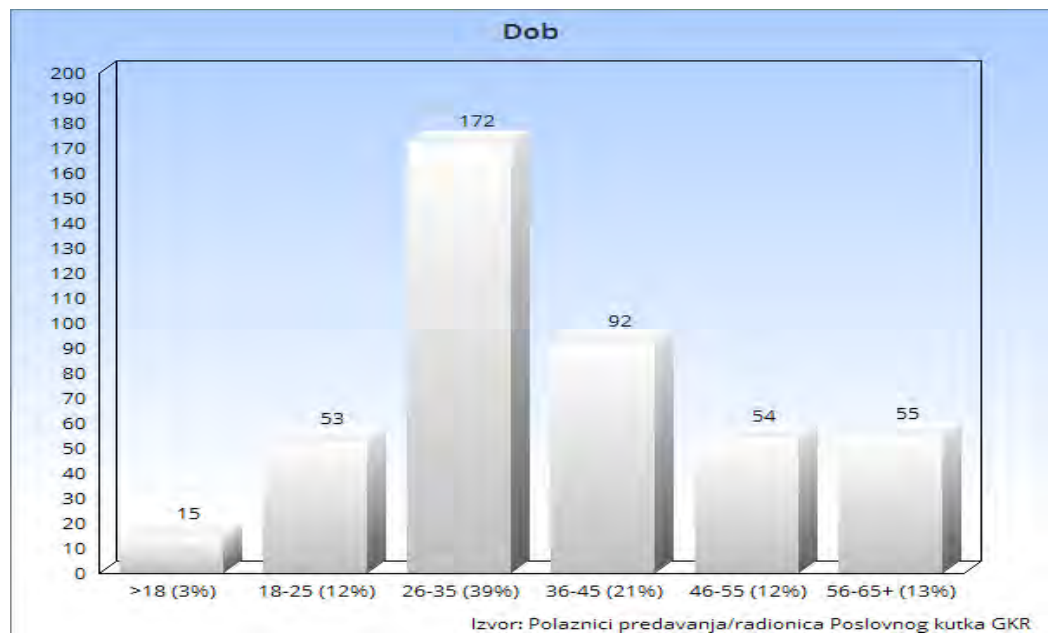

Slika 1. Polaznici predavanja/radionica Poslovnog kutka prema dobi

Na slici 1 vidljivo je da je najveći broj polaznika predavanja/radionica, njih 172 (39\%), u dobi od 26 do 35 godina, 92 (21\%) u dobi od 36 do 45 godina. Najmanje polaznika predavanja/radionica u dobnoj je skupini mlađoj od 18 godina, njih ukupno 15 (3\%).

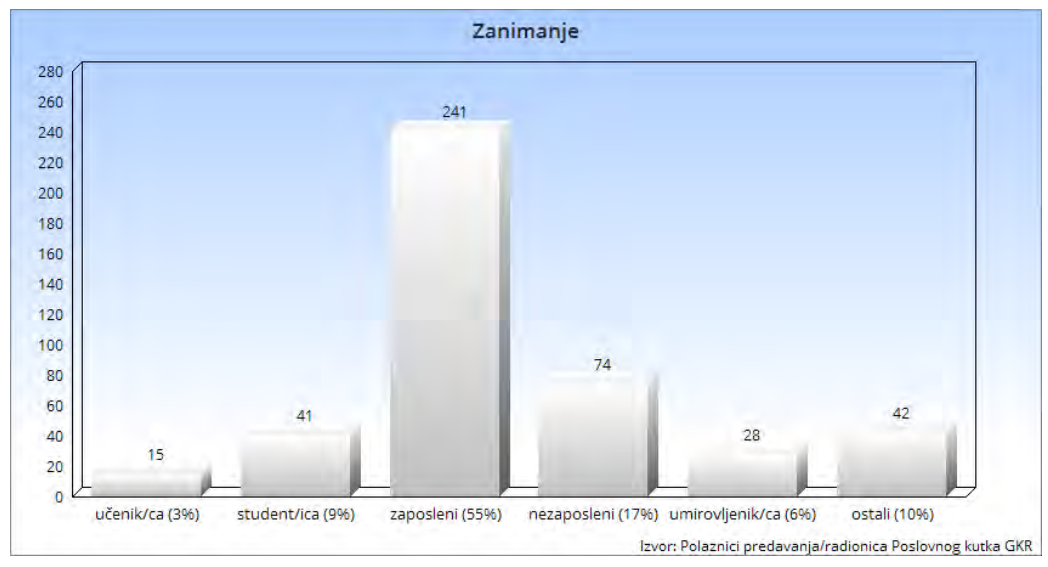

Slika 2. Polaznici predavanja/radionica Poslovnog kutka prema zanimanju 
Iz slike 2 možemo zaključiti da 241 zaposleni polaznik, odnosno njih $55 \%$, čini najbrojniju skupinu među polaznicima predavanja/radionica Poslovnog kutka. Slijede 74 nezaposlena polaznika (17\%), 42 ostala (10\%) te 41 student (9\%). Skupina učenika najslabije je zastupljena među polaznicima (3\%), a ispred nje je skupina umirovljenika (6\%).

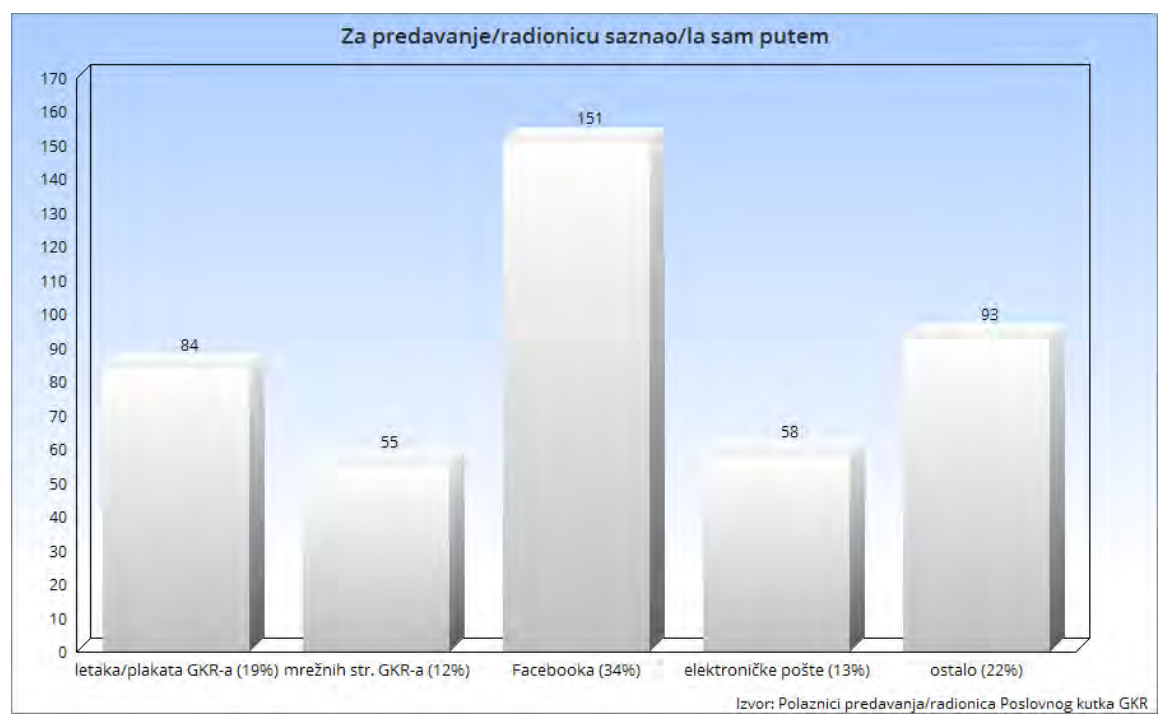

Slika 3. Način informiranja o održavanju predavanja/radionice Poslovnog kutka

Kako je vidljivo iz slike 3, najviše polaznika za događanja je saznalo putem Facebooka, i to njih 151 (34\%). Slijedi skupina označena kao ostalo, njih 93 (22 \%) koji su kao mjesto informiranja o održavanju predavanja/radionice naveli: K.E.Š. Kreativno edukativnu školu za mlade poduzetnike, Novi list, prijatelje, kolege, Radio Rijeku, Step-Ri, Znanstveno-tehnologijski park Sveučilišta u Rijeci, usmenu predaju, Medicinsku školu Rijeka, školsku knjižnicu, STARTUP inkubator Rijeka, frizerku... Putem letaka i plakata u prostoru Gradske knjižnice Rijeka za predavanje/radionicu saznalo je njih 84 (19\%), putem elektroničke pošte 58 (13\%), a najmanje putem mrežnih stranica GKR-a - njih 55 (12\%). 


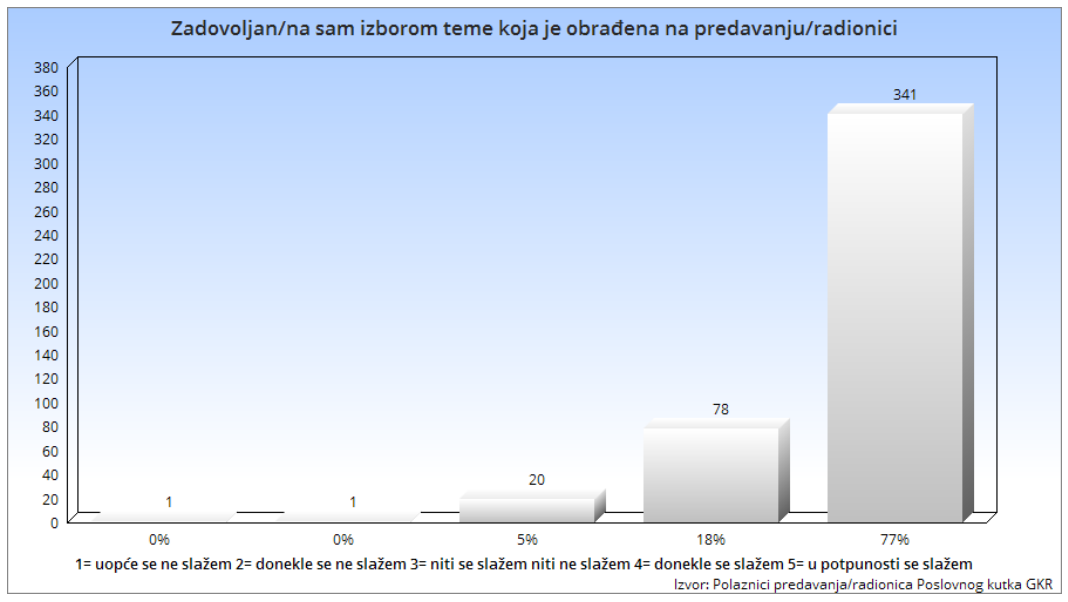

Slika 4. Razina zadovoljstva izborom teme koja je obrađena na predavanju/radionici

Ispitujući razinu zadovoljstva polaznika predavanja/radionica izborom teme, većina ispitanika, njih 341 (77\%), označila je „u potpunosti se slažem“ (slaganje s tvrdnjom „Zadovoljan/na sam izborom teme koja je obrađena na predavanju/ radionici“) te „donekle se slažem“, njih 78 (18\%) (slika 4).

Manji broj polaznika radionica, njih 20 (5\%), niti se slaže niti ne slaže s tvrdnjom da je zadovoljan/na izborom teme koja je obrađena na predavanju/radionici, a zanemariv broj od po jednog polaznika donekle se ili uopće ne slaže s tvrdnjom.

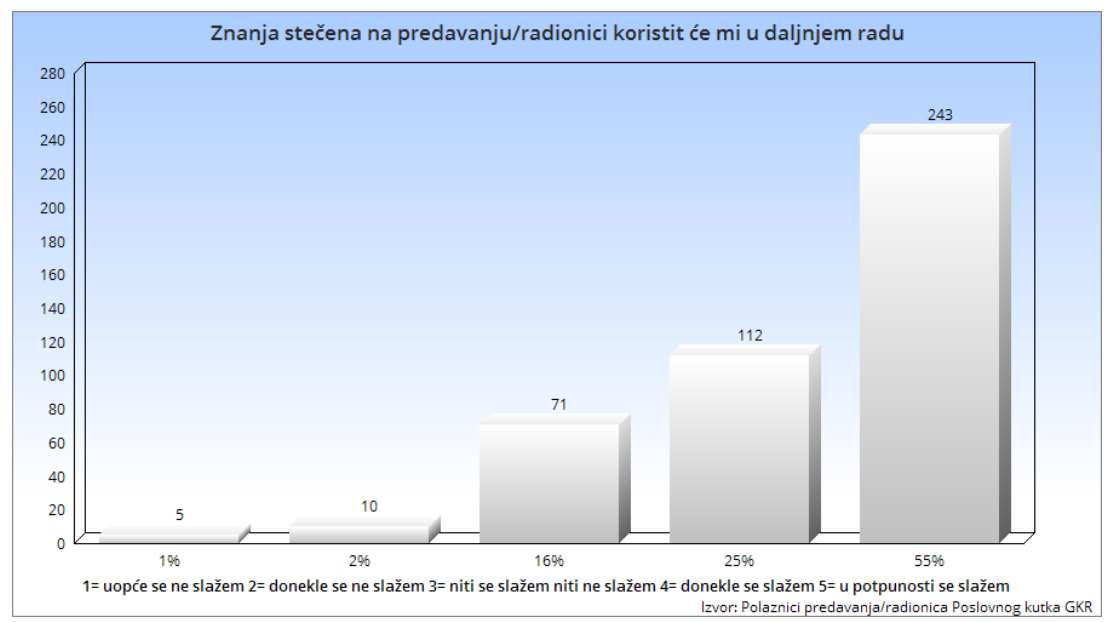

Slika 5. Ocjena korisnosti znanja stečenih na predavanju/radionici za daljnji rad 
Da će im znanja stečena na predavanju/radionici koristiti u daljnjem radu, u potpunosti se slažu 243 polaznika predavanja/radionica (55\%), dok se s tim donekle slaže njih $112(25 \%)$. S tvrdnjom se niti slaže niti ne slaže 71 polaznik predavanja/radionica (16\%), dok se vrlo mali broj donekle ne slaže, njih $10(2 \%)$ ili uopće ne slaže, njih 5 (1\%) (slika 5).

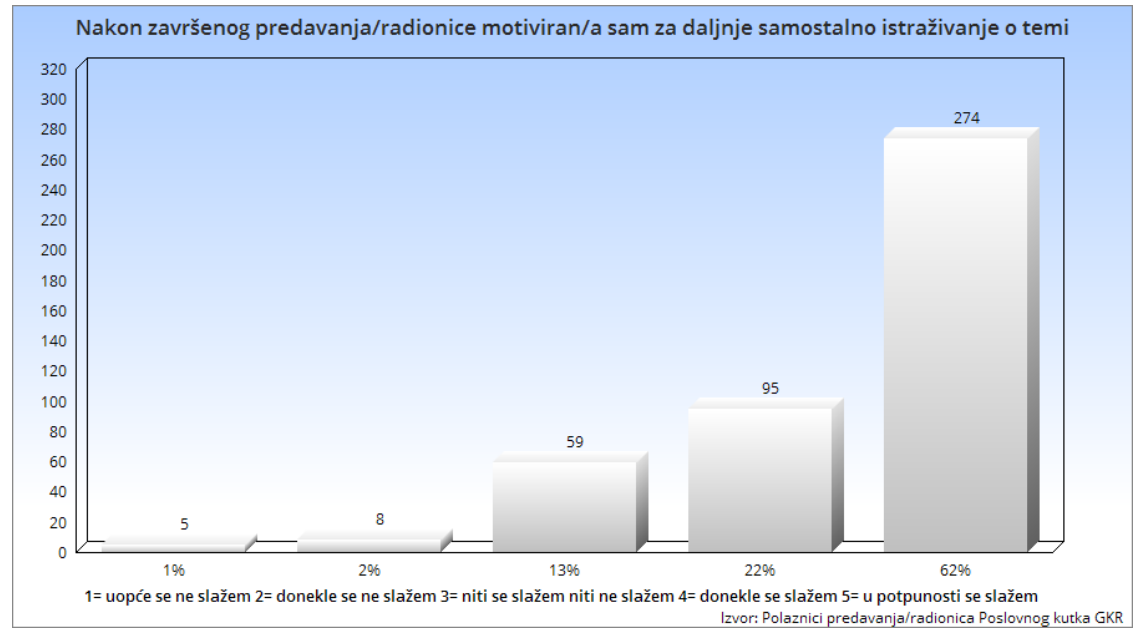

Slika 6. Motiviranost za daljnje samostalno istraživanje o temi predavanja/radionice

Što se tiče motivacije za daljnje samostalno bavljenje temom nakon predavanja/radionice, potpuno slaganje s tvrdnjom „Nakon završenog predavanja/radionice motiviran/a sam za daljnje samostalno istraživanje o temi“" izrazila su 274 polaznika (62\%), dok se s istom tvrdnjom donekle slaže njih 95 (22\%). Niti se slaže niti ne slaže njih 59 (13\%). U manjini su polaznici predavanja/radionice koji se donekle ne slažu - njih $8(2 \%)$ - ili uopće ne slažu - njih $5(1 \%)$ - s tvrdnjom da su nakon predavanja/radionice motivirani za daljnje samostalno istraživanje o temi (slika 6).

S obzirom na to da među polaznicima predavanja/radionica Poslovnog kutka njih 154 (35\%) nisu članovi Knjižnice, otvara se prilika za daljnju promociju knjižničnih usluga među građanima. Također, na temelju podatka o 163 muškarca (37\%) te 278 žena (63\%) među polaznicima predavanja/radionica Poslovnog kutka možemo zaključiti da su žene proaktivnije od muškaraca. Kao vodeći komunikacijski kanal istaknula se društvena mreža Facebook, putem koje se o održavanju predavanja/radionice Poslovnog kutka informirao 151 polaznik, odnosno njih $34 \%$. Ispunjena su i očekivanja Poslovnog kutka o tome kojoj se ciljnoj skupini obraća u smislu dobi i radnog statusa. 
Iz rezultata zaključujemo da su polaznici predavanja/radionica najbolje ocijenili zadovoljstvo izborom teme koja je obrađena na predavanju/radionici. Njih $95 \% \mathrm{u}$ potpunosti se ili donekle složilo s tvrdnjom da su zadovoljni izborom teme koja je obrađena na predavanju/radionici. Velik je dio njih motiviran za daljnje samostalno istraživanje o temi predavanja/radionica $(84 \%$ se u potpunosti ili donekle slaže s tvrdnjom), a njih $80 \%$ u potpunosti se ili donekle slaže s tvrdnjom da će im znanja stečena na predavanju/radionici koristiti u daljnjem radu. Velik odaziv predavača koji predavanja i radionice u Poslovnom kutku izvode isključivo na volonterskoj bazi, brojnost polaznika i pozitivna evaluacija usluge poticaj su za daljnje planove razvijanja usluge.

\section{Aktualno u Poslovnom kutku}

Kao što je ranije navedeno, oko Poslovnog kutka okupila se stabilna korisnička skupina koja aktivno prati događanja, komentira ih na Facebook-stranici i promovira dalje. Od strane te skupine korisnika dolaze prijedlozi tema i sadržaja za buduće aktivnosti. Prijedloge koji se ponavljaju od strane većeg broja sudionika nastoji se realizirati kroz predavanja/radionice/rasprave.

U tijeku je realizacija suradnje s Hrvatskom obrtničkom komorom PGŽ-a. Upravo je završen program promocije obrtničkih zanimanja u okviru kojega su zainteresirani učenici osmih razreda osnovnih škola grada Rijeke i riječkog prstena sudjelovali na, za njih pripremljenim, radionicama („Biti cvjećar je in“, „Drvo je prvo“ $i$, Kako se sunčeva energija pretvara u izmjeničnu struju“) te je sve skupa okončano panel-raspravom „Postani obrtnik - školovanje, zapošljavanje, osnivanje obrta...". U tom programu sudjelovali su Obrtnička komora PGŽ-a, Hrvatski zavod za zapošljavanje, Regionalni ured Rijeka, StepRi, Znanstveno-tehnologijski park Sveučilišta u Rijeci, osnovne škole grada Rijeke i riječkog prstena, Graditeljska škola za industriju i obrt, Strojarsko-brodograđevna škola za industrijska i obrtnička zanimanja te obrtnici otvoreni za suradnju. Pred nama je „Studeni mjesec financijske pismenosti u Poslovnom kutku“.

\section{Zaključno}

U tranzicijskom procesu u kojemu se narodne knjižnice od knjižničnih zbirki okreću potrebama korisnika, novi koncept knjižnične usluge oslanja se na pitanje kako knjižnica može pomoći društvenim potrebama. U tom smislu usluga Poslovni kutak nalazi se u samom središtu interesa građana zbog opće potrebe društva za dinamiziranjem poslovnih i poduzetničkih aktivnosti te potreba građana za iscrpnim informacijama, poticajima, ohrabrenjima te sveopćom podrškom vezanom uz zapošljavanje i pokretanje poslovanja.

Novi koncept uključuje i suradnju u zajednici, posebno s javnim sektorom. 
Kroz Poslovni kutak želimo pripomoći još jednoj važnoj zadaći kojoj ćemo se posvetiti u vremenu koje je pred nama: većoj i učinkovitijoj participaciji građana $\mathrm{u}$ životu zajednice.

\section{LITERATURA}

The British Library's Business \& IP Centre. [citirano: 2018-10-1]. Dostupno na:https:// www.bl.uk/business-and-ip-centre.

E-Građani - statistika. [citirano: 2018-12-27]. Dostupno na: https://data.gov.hr/ dataset/e-gradjani-statistika.

Horvat, A. Knjižnice u službi svoje zajednice. // Knjižnica kao komunikacijsko i multikulturalno središte lokalne zajednice / 8. Savjetovanje za narodne knjižnice u Republici Hrvatskoj; priredila za tisak Jelica Leščić. Zagreb: Nacionalna i sveučilišna knjižnica, 2012. Str. 21-32.

IFLA. International Advocacy Programme (IAP). [citirano: 2019-1-3]. Dostupno na: https://www.ifla.org/ldp/iap.

Novi izazov: globalni ciljevi održivog razvoja do 2030. Zagreb: Odraz, 2015. [citirano: 2019-10-1]. Dostupno na: http://odraz.hr/media/291518/globalni\%20ciljevi\%20 odrzivog\%20razvoja\%20do\%202030_web.pdf.

Poslovna knjižnica. // Gradska knjižnica „Ivan Goran Kovačić“ Karlovac [citirano: 2018-10-1]. Dostupno na: http://www.gkka.hr/poslovna-knjiznica/.

Pulman-smjernice. [citirano: 2018-09-20]. Dostupno na: https://gkr.hr/content/downlo$\mathrm{ad} / 1799 / 20700 / . . / 2 / . . . /$ Pulman\%20smjernice\%20(1).doc.

Udiljak Bugarinovski, Z.; D. Pšenica. Poslovna knjižnica. // Knjižnice: kamo i kako dalje?: zbornik radova / 14. dani specijalnih i visokoškolskih knjižnica; uredile Dina Mašina i Kristina Kalanj. Zagreb: Hrvatsko knjižničarsko društvo, 2017. Str. $217-$ 225.

Velagić, Z. Povijesnost koncepcije knjižničnoga trećeg prostora. // Narodne knjižnice kao treći prostor : zbornik radova / 9. savjetovanje za narodne knjižnice u Republici Hrvatskoj Zagreb: Nacionalna i sveučilišna knjižnica, 2015. Str. 29-42. 